\title{
REACHING STATELESS, UNDOCUMENTED AND MIGRANT COMMUNITIES DURING THE COVID-19 PANDEMIC: LESSONS FROM THE GRASSROOTS HUMANITARIAN EFFORT IN SABAH, MALAYSIA
}

\author{
MARY ANNE K BALTAZAR* AND AMANDA R CHEONG**
}

\section{TABLE OF CONTENTS}

I Introduction

II A Community-Based Social Listening Approach.

A Tailored and Targeted Public Health Messaging...................................... 133

B Community-Based Social Listening Tools................................................ 136

C The Impacts of COVID-19 on Stateless and Legally Marginalised

Communities in Sabah............................................................................ 137

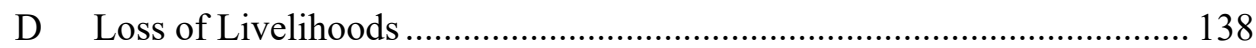

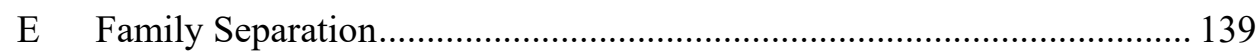

F The Obstructive Impacts of Anti-Immigrant Crackdowns on the Public

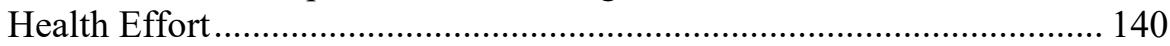

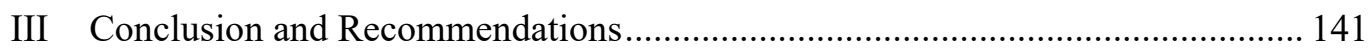

A Treat Stateless People as Humans, Not Security Risks ............................. 141

B Listen, Learn and Adapt ....................................................................... 141

C Recognise That Health is a Human Right, Regardless of One's Legal Status

\section{INTRODUCTION}

In May 2020, the United Nations Refugee Agency issued a statement emphasising the particular vulnerabilities faced by stateless populations during the global COVID-19 crisis. In stating that 'nobody can be protected unless everybody is

* Mary Anne K Baltazar is an MA student in International Relations at the Universiti Malaysia Sabah and Fellow in the UMS-UNICEF Communications for Development Research Unit. She has 12 years of experience in human rights and non-profit work, specialising in statelessness, migration and children's rights. Mary Anne is the founder of ANAK, an NGO that advocates for the rights of non-citizen children in Sabah, East Malaysia.

** Amanda R Cheong is an Assistant Professor of Sociology at the University of British Columbia. Her research explores the links between legal status and the reproduction of inequality, with a focus on stateless, undocumented and refugee populations. Amanda is currently writing a book, entitled Omitted Lives, which is an ethnography of the causes and consequences of exclusion from civil registration systems in Malaysia. For their generous financial and technical support, we thank Alexander Douglas and Maude Morrison from the Centre for Humanitarian Dialogue. We also thank the International Development Research Center and the International Union for the Scientific Study of Population's CRVS Fellowship, which provided us with the resources to collaborate on this information dissemination initiative. Finally, we thank Sumitha Shaanthinni Kishna, Director of Our Journey, for providing food aid support for our communities, and to the indomitable Dr Kathryn Rivai of Etania Schools who was instrumental in facilitating our emergency aid provision effort. 
included, and that means including often invisible, stateless populations' ${ }^{1} \mathrm{UN}$ High Commissioner for Refugees Filippo Grandi highlighted two issues: 1) COVID-19 has not only exposed, but has moreover exacerbated existing inequalities, including those operating along the dimension of legal status; and 2) the protracted exclusion of stateless peoples may undermine governments' efforts to protect the health of their populations' recognised citizens. Grandi's comments echo recommendations from the World Health Organization and other international bodies that governments 'leave no one behind' in their responses to COVID-19. ${ }^{2}$ Yet, in many contexts, stateless persons and others who are legally marginalised have not adequately been factored into policies for managing COVID-19.

Such realities are all too apparent in Malaysia, which is home to a significant, albeit unknown, number of stateless persons, irregular migrants and their descendants. Statelessness impacts a diverse cross-section of the Malaysian population and is a status not exclusive to migrants. Rather, statelessness is 'homegrown' in Malaysia, affecting generations of people who were born and raised in the country, but for various reasons are nevertheless denied political membership. ${ }^{3}$ The majority of stateless and undocumented persons in Malaysia live in the state of Sabah, East Malaysia, and are predominantly composed of people of Indonesian and Filipino descent who are excluded from a range of basic rights and protections, including freedom from arbitrary detention and deportation, education and healthcare. ${ }^{4}$

Malaysia's early successes in managing the pandemic were disrupted by a surge in cases which were disproportionately concentrated among non-citizens. These series of outbreaks, which began around May 2020 in Peninsular Malaysia, ${ }^{5}$ exposed the consequences of the Malaysian Government's chronic marginalisation of its non-citizens. Stateless persons and undocumented migrants in Malaysia contend with a number of legal, social and economic exclusions that amplify their health risks, including a lack of eligibility for social safety net protections, cramped living conditions, employment in high-risk labour market sectors and the constant risk of arrest and detention. ${ }^{6}$ Rather than adopt more inclusive measures to manage the spread of COVID-19 among the most vulnerable segments of society, the Malaysian Government has doubled down on its exclusionary and punitive stance toward non-citizens. Early interventions took the form of an extended and large-scale crackdown on 'illegal' immigration, along

1 'UNHCR Warns Stateless People Risk Being Left Behind in Coronavirus Response', UNHCR (Web Page, 11 May 2020) <https:/www.unhcr.ca/news/unhcr-warns-stateless-people-riskbeing-left-behind-covid-19-response/> ('UNHCR').

2 'Leave No One Behind', United Nations Sustainable Development Group (Web Page) $<$ https://unsdg.un.org/2030-agenda/universal-values/leave-no-one-behind $>$.

3 Jamie Liew, 'Homegrown Statelessness in Malaysia' (2019) 1(1) Statelessness \& Citizenship Review 95, 97.

4 Rodziana Mohamed Razali, Addressing Statelessness in Malaysia: New Hope and Remaining Challenges (Working Paper 2017/9, Institute on Statelessness and Inclusion, December 2017) $<$ https://files.institutesi.org/WP2017 09.pdf>.

5 Andika Wahab, 'The Outbreak of Covid-19 in Malaysia: Pushing Migrant Workers at the Margin' (2020) 2(1) Social Sciences \& Humanities Open, 2.

6 Malaysia: Undocumented Children in Sabah Vulnerable to Statelessness (Bulletin, Refugees International 13 June 2007) <https://www.refworld.org/docid/47a6ee98d.html>. 
with the promulgation of discourses explicitly scapegoating migrants as vectors for disease and thereby justifying their arrest and detention. ${ }^{7}$

These actions have exacerbated two major problems confronting stakeholders engaged in managing the pandemic: 1) the state's punitive approach disincentivises contact with mainstream institutions, making it difficult to monitor the status and wellbeing of stateless and undocumented communities during the pandemic; and 2) mainstream public health messaging may not be suitable for stateless and irregular migrant audiences given their specific needs and constraints. Thus, the Government's protracted exclusion of undocumented and stateless populations has created a blind spot in Malaysia's pandemic response, heightening non-citizens' risk of exposure to infection, and undermining the COVID-19 management effort at national and regional levels.

Advocates for Non-discrimination and Access to Knowledge ('ANAK') - a grassroots community-based organisation founded by author Mary Anne Baltazar to serve stateless, undocumented and migrant communities in Sabah — has been working to address this blind spot. In the wake of the pandemic, ANAK focused on providing emergency humanitarian aid to stateless and irregular migrant communities that had been forsaken by the Malaysian Government. Based on ANAK's work on the ground, the authors argue that the wellbeing of stateless and other legally vulnerable populations should be a central, rather than a marginal, priority in any effective COVID-19 pandemic response. Expanding basic rights to stateless populations, including healthcare, education and citizenship, is a necessary precondition for building a robust and inclusive public health infrastructure that 'leaves no one behind'. ${ }^{8}$ Such efforts of inclusion must not be temporary or contingent - ie, in reaction to crises such as COVID-19 — but should be permanent acknowledgements of the longstanding contributions of stateless communities to the Malaysian nation. Extending protections to the most legally marginalised and vulnerable is not a zero-sum game, but is beneficial to the safety and wellbeing of whole societies.

\section{A COMMUNITY-BASED SOCIAL LISTENING APPROACH}

Drawing on ANAK's background in community-based advocacy, the organisation disseminated information to, and documented the experiences of, stateless and legally marginalised families as they navigated the COVID-19 crisis on the margins of Sabahan society.

\section{A Tailored and Targeted Public Health Messaging}

Mainstream public health information about COVID-19 was not suitable for stateless audiences, some of whom may be illiterate, speak dialects other than the

7 R Loheswar, 'Muhyiddin: Undocumented Migrants Cause of Sabah's Covid-19 Situation, More Detention Centres to be Opened', Malay Mail (online, 3 October 2020) $<$ https:/www.malaymail.com/news/malaysia/2020/10/03/muhyiddin-undocumentedmigrants-cause-of-sabahs-covid-19-situation-more-det/1909146>. 
national language of Bahasa Malaysia and consume information on different platforms to Malaysian citizens. ${ }^{9}$

ANAK tailored public health information about the following: methods for preventing the spread of COVID-19, suggested actions to take if an individual is believed to have contracted COVID-19, guidance for accessing aid and assistance, and government rules and regulations regarding permitted actions during the pandemic. ANAK identified reputable information sources (such as the Malaysian Ministry of Health, state-level ministries, and the World Health Organization) and worked to repost, translate, or adapt information to render them more accessible to the target demographics. ANAK mapped out key organisations that hold influence among these target demographics and collaborated to amplify these messages. ANAK produced materials in a variety of languages and dialects, including Bajau, Suluk, Bugis, Tagalog, Visaya and Bahasa Indonesia. To reach audiences that may be illiterate, ANAK created visual-dominant infographics and informational videos. ANAK also considered that stateless and legally marginalised families may not have access to the kinds of amenities likely available to Malaysian citizens, such as running water and soap, and made a video demonstrating how ash can be used to clean hands where soap is not available. These messages were disseminated using social media advertising tools, which enabled ANAK to reach the intended demographics more effectively.

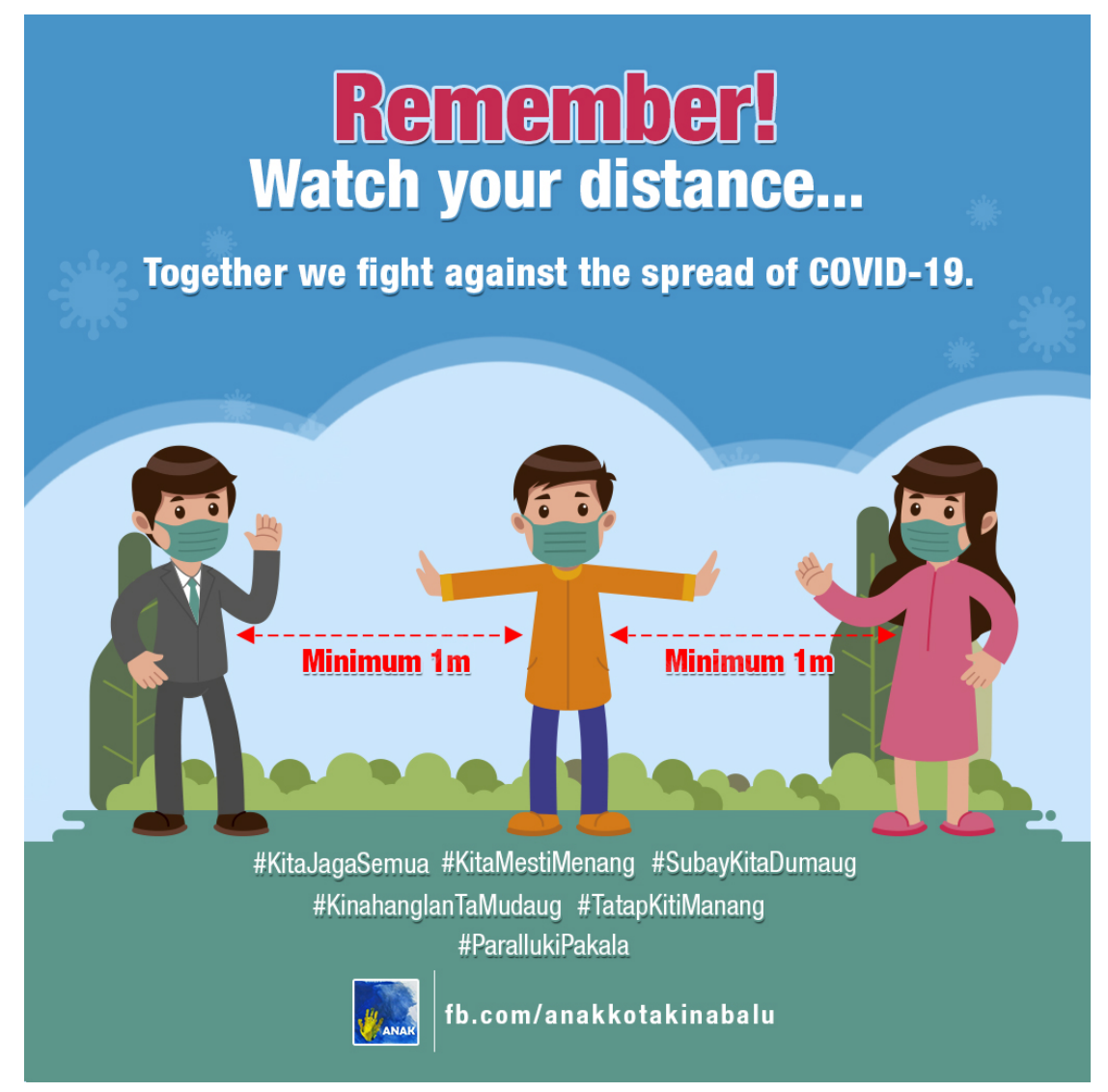

9 Kathryn Rivai, The Challenges of Literacy Acquisition and Learning among the Children of Migrant Labourers in Sabah (Conference Paper, The 2nd International Conference and $\begin{array}{llllll}\text { Linguistics on Language Teaching (I-Collate) } 20 & \text { October 2021) } 27\end{array}$ $<$ https://www.researchgate.net/profile/Rika-

Mutiara/publication/332184673_Expressions_of_disagreement_in the textbok_and_copror a/links/5ca55d3b458515f78522 2 c3e/Expressions-of-disagreement-in-the-textbok-andcoprora.pdf\#page $=56>$. 


\section{Informitnt Piyanin lawak bi..}

Magbiya kitam pa halli kalaminan sakki COVID-19.

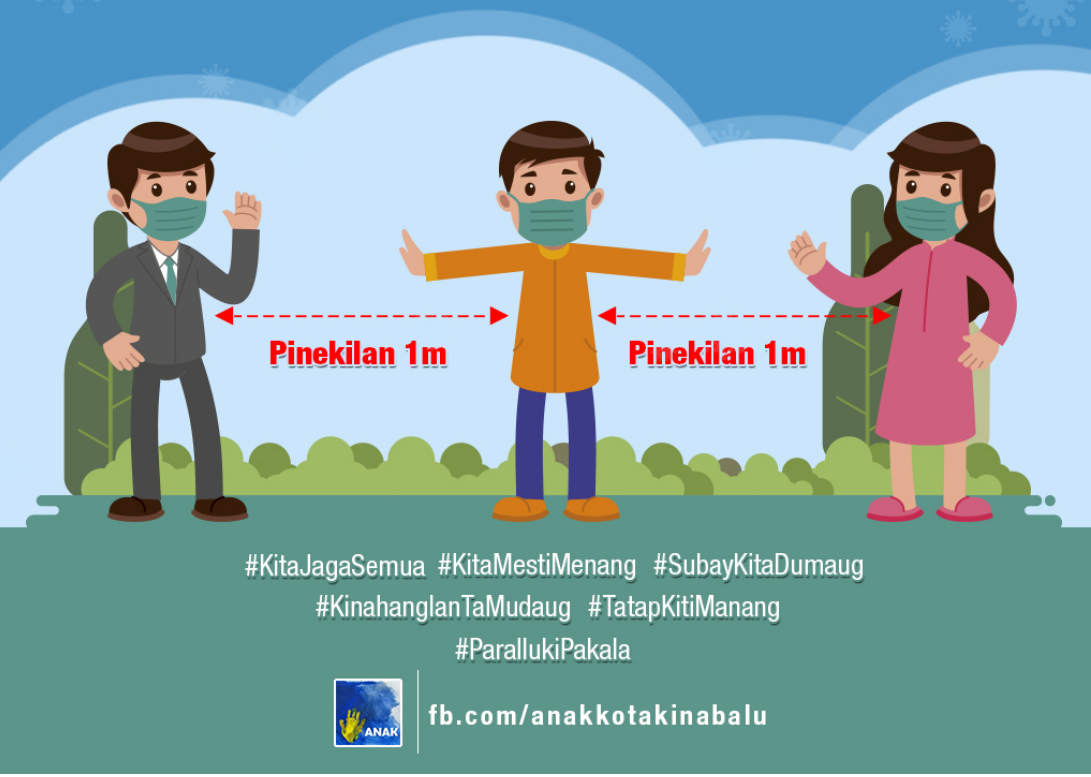

\section{Tumftuma niyu Paglawak-lawak kamu ha...}

Magsama-sama lumayu' dayng ha panglamin sin COVID-19

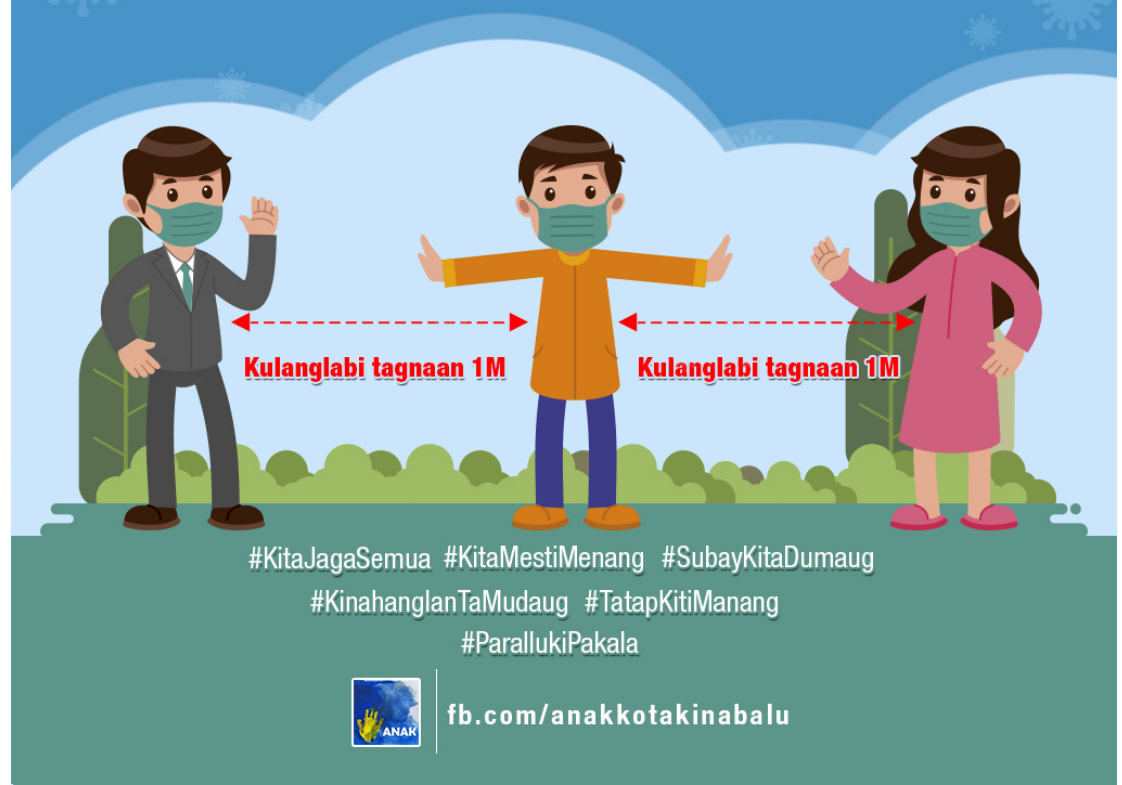

Figure 1: Social distancing infographics in English, Bajau and Suluk languages. Graphics by ANAK member Akhdan Shah Sheikh Sabang. 


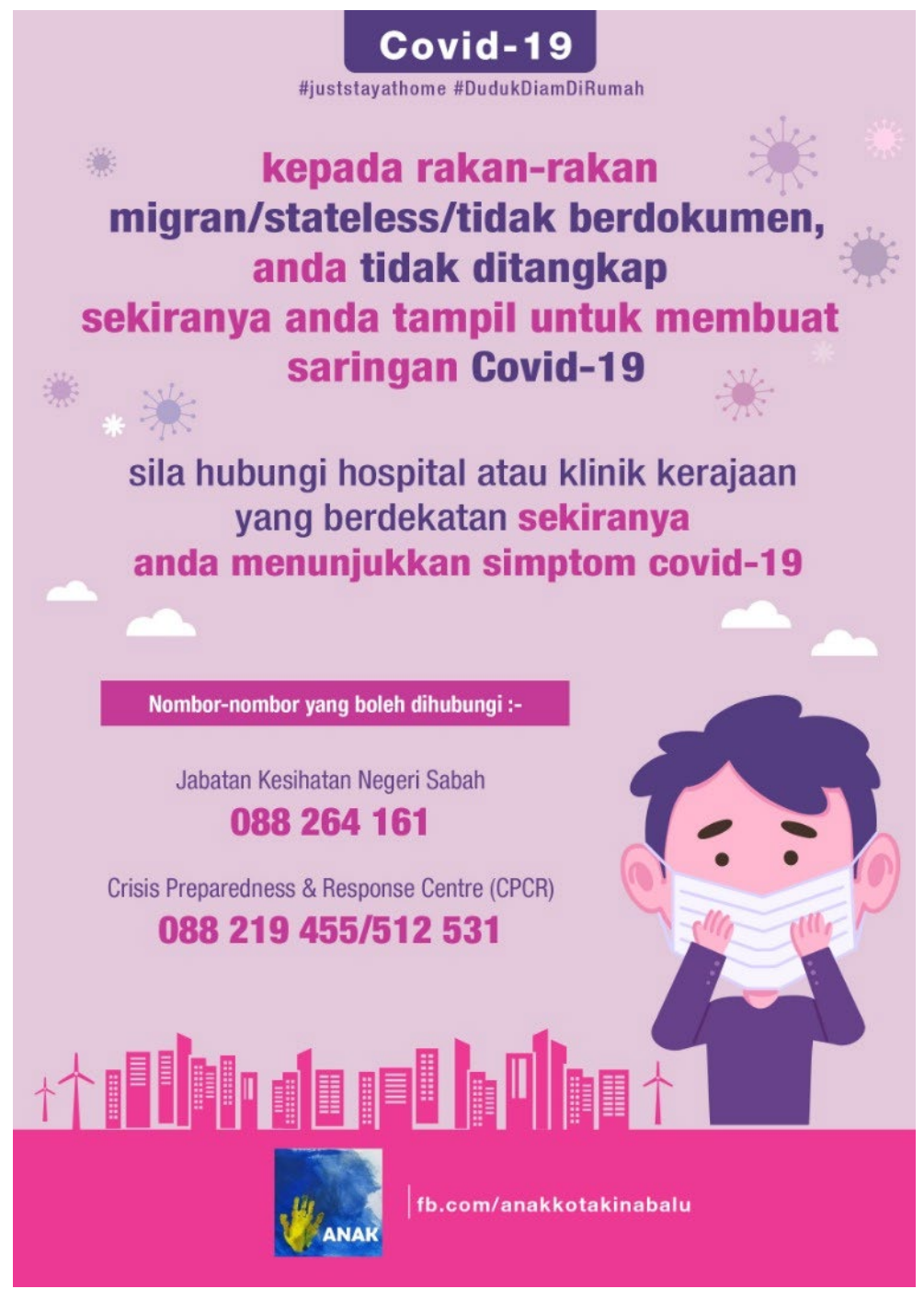

Figure 2: An infographic in Bahasa Malaysia informing migrants, stateless and undocumented persons of the Government's announcement that they would not be arrested if they come forward for COVID-19 screening. This post went viral and was shared 229 times. Graphics by ANAK member Akhdan Shah Sheikh

Sabang.

\section{B Community-Based Social Listening Tools}

Pandemic-related restrictions on movement obstructed ANAK's ongoing interactions with the stateless and undocumented communities. This required ANAK to use new tools to maintain its understanding of the challenges they faced. Rather than only broadcasting messages, ANAK wanted its communication channels to be multi-directional. Through 'social listening,' ANAK utilised its communication platforms to better understand the families it serves and ensure that ANAK's work was in line with their needs and priorities.

Two strategies were employed: community journaling and online focus group dialogues. Community journaling allowed ANAK to gain an in-depth, longitudinal understanding of how COVID-19 impacted people's everyday lives. The organisation selected two individuals in the central Sabah town of Keningau and 
two individuals in the state capital city of Kota Kinabalu and followed their lives for three weeks. Weekly (distanced) interviews were conducted to gain a better understanding of their lives prior to the pandemic, during the pandemic, and their prospective plans. Between interviews, the participants photo-journaled elements of their daily lives during COVID-19.

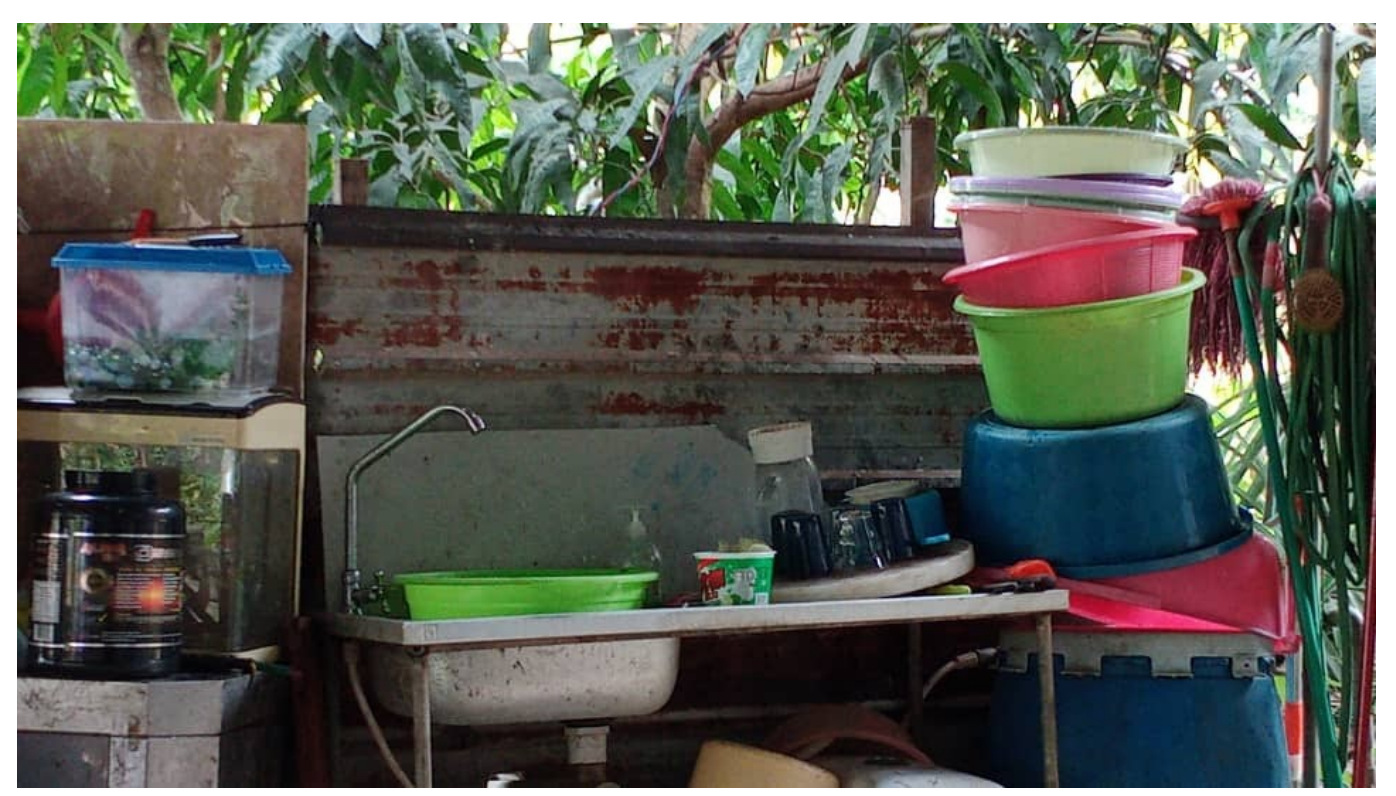

Figure 3: Community photo-journaling provides intimate insight into the everyday experiences of legally marginalised families during the pandemic. This photograph was taken by a migrant father, who built an outdoor sink for his family members to wash their hands before entering their home.

ANAK also conducted mobile-based focus group dialogues among key demographic groups within the targeted communities: youth, women, men and the elderly. Groups of five persons representing each of these demographics were convened using WhatsApp, a mobile phone-based instant messaging platform. Participants discussed their knowledge and awareness about COVID-19, perceptions and understandings about government policies and from where participants sourced their information. This information was crucial for developing ANAK's online content, including infographics and videos.

\section{The Impacts of COVID-19 on Stateless and Legally Marginalised}

\section{Communities in Sabah}

Based on ANAK's experiences providing emergency aid to communities on the ground and the information collected through social listening mechanisms, the authors identify a number of particular challenges and vulnerabilities experienced by stateless and legally marginalised families during the early months of the COVID-19 pandemic in Sabah. 

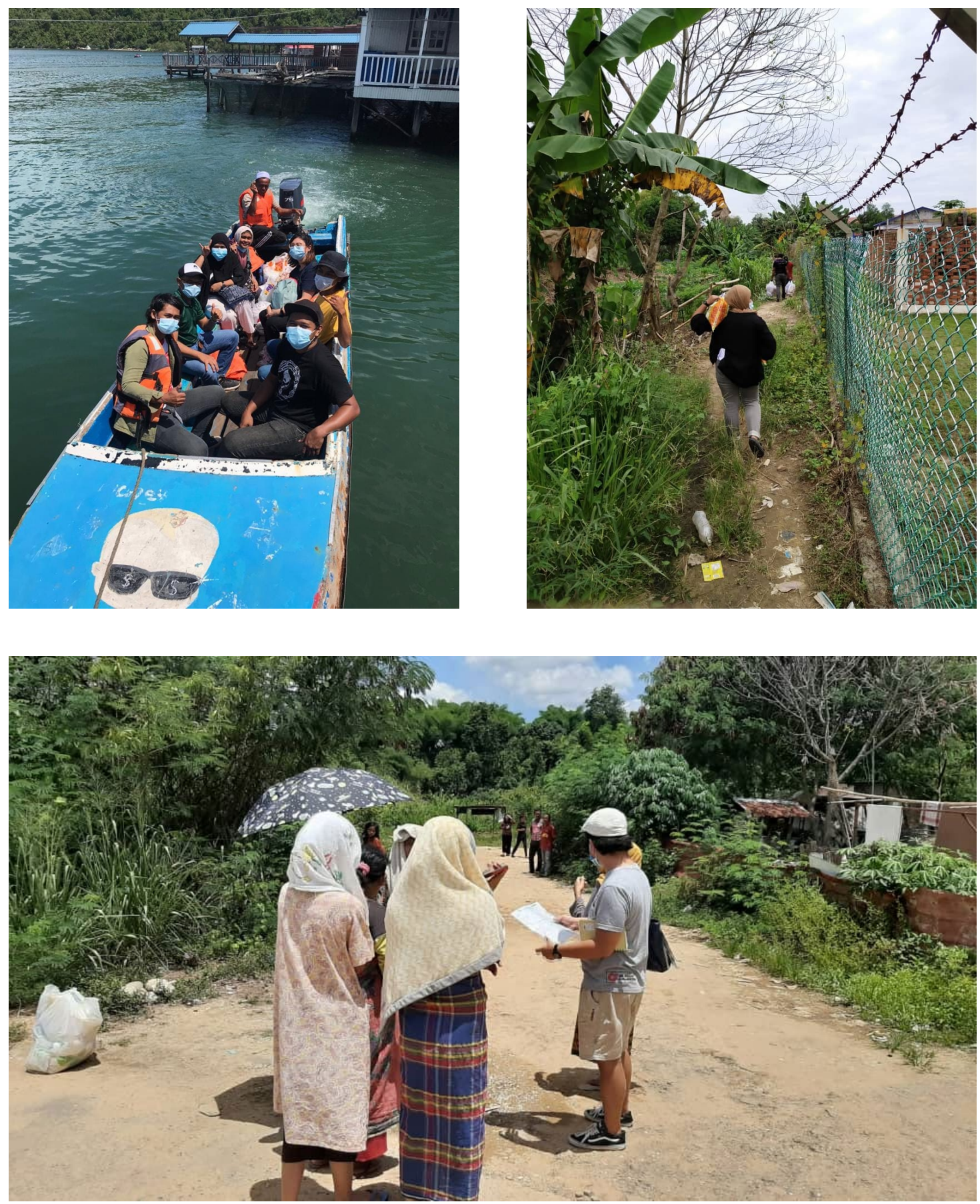

Figure 4: ANAK team members delivering food aid to communities in need.

\section{Loss of Livelihoods}

On 18 March 2020, the Malaysian Government instituted a nationwide Movement Control Order ('MCO'), which closed down all government and private premises except essential services such as healthcare, utilities and supermarkets. Roadblocks were set up and movement was restricted, with only one person allowed to go out for the purposes of getting basic necessities or medication within 
a specified curfew. ${ }^{10}$ Violators of the MCO faced a maximum fine of MYR1,000 under the Prevention and Control of Infectious Diseases Act 1988.11 A stimulus package $^{12}$ was announced to ease financial problems arising from the MCO such as food baskets and one-off cash assistance of MYR500 to MYR1,600 depending on the household's income. ${ }^{13}$ However, this assistance was only offered to Malaysian citizens, leaving non-citizens to survive on their own.

For stateless and legally marginalised communities in Sabah, the MCO had particularly devastating effects on their abilities to earn a livelihood. Most are employed informally in daily wage jobs in sectors such as construction, agriculture, and in services such as food and beverage and domestic work. Forms of labour typically performed by stateless and legally marginalised persons are often characterized as being '3D' (dirty, dangerous and difficult) and do not come with benefits such as health or unemployment insurance, nor strong labour protections. ${ }^{14}$ In the wake of the economic downturn triggered by the pandemic, stateless and legally marginalised persons found themselves without their regular sources of income. Many families that ANAK aided had already been in a state of subsistence living, and had no choice but to ration their foodstuffs and rely on charitable donations from NGOs and faith-based associations when the pandemic hit. Barred from opening bank accounts due to a lack of citizenship and/or identity documentation, some 'unbanked' people ANAK encountered were also compelled to sell any savings they had kept in the form of gold in exchange for petty cash to afford immediate needs.

\section{E Family Separation}

Some families that were assisted by ANAK resorted to sending their children to stay with other relatives because they had insufficient means to provide for their basic needs. These and other forms of family separation, particularly those spanning national borders, took a great financial and emotional toll. For example, Julia, a Filipina living in Sabah, was almost due to give birth when her husband's mother fell sick in the Philippines. ${ }^{15}$ Their plan was for her husband to visit his mother and come back in time for the birth of their baby. Due to the border shutdown, Julia's husband was not able to come back, leaving Julia alone to care for their five-year-old son while pregnant, meaning that she was unable to leave her home to work. In July 2020, she gave birth to a baby girl at home. Despite assistance from friends and NGOs in the form of food, medical aid, and rent support, she was evicted from her room as she was unable to pay rent. Currently, Julia and her children are staying with a friend while they wait anxiously to be reunited with the children's father.

10 'Only One Person Allowed Out', The Star (online, 22 March 2020) $<$ https://www.thestar.com.my/news/nation/2020/03/22/only-one-person-allowed-out>.

11 Prevention and Control of Infectious Diseases Act 1988 (Malaysia).

12 Ain Umaira Md Shah et al, 'COVID-19 Outbreak in Malaysia: Actions Taken by the Malaysian Government' [2020] 97 International Journal of Infectious Diseases 108, 113.

13 Tan Sri Muhyidden Yassin, 'Prihatin Rakyat Economic Stimulus Package (PRIHATIN) Speech Text' (Speech, Prime Minister's Office of Malaysia, 27 March 2020) $<$ https://www.pmo.gov.my/2020/03/speech-text-prihatin-esp/>.

14 Trapped: The Exploitation of Migrant Workers in Malaysia (Report, Amnesty International 24 March 2010) <https://www.refworld.org/docid/4bb05b812.html>.

15 All names used in this article are pseudonyms to protect the identities of our community members. 


\section{Health Effort}

During the pandemic, the Government reinforced its punitive approach to noncitizens, building on a long history of exclusionary treatment which has included arrest, harassment, extortion and detention. Measures such as immigration raids and crackdowns obstruct public health efforts because they further marginalise and alienate stateless persons and migrants, and disincentivise them from making contact with public health institutions.

For example, in May 2020, on the eve of Labour Day during Ramadan, the Government launched an immigration crackdown in Peninsular Malaysia. Migrants and undocumented persons were arrested and confined in detention centres, which became COVID-19 hotspots due to overcrowding, poor sanitation and noncompliance with health measures during the arrest process. ${ }^{16}$ The Government blamed migrants for the spread of COVID-19 domestically. ${ }^{17}$

While such actions and discourses unfolded in Peninsular Malaysia, feelings of marginalisation were similarly present in Sabah. For example, Dayah, an undocumented Bajau mother of four living on Gaya Island near Kota Kinabalu, explained how testing and document checks made her daily commute to work a risky venture. Gaya Island, known for its large stateless and undocumented settlements, was the site of a mandatory mass COVID-19 screening in March 2020 due to an outbreak among local residents. ${ }^{18}$ She and her family endured distress and uncertainty, despite assurances that no arrests would be made among migrants who cooperated with the testing exercise. ${ }^{19}$ Similarly, during a routine COVID-19 screening on Omadal Island in the east coast district of Semporna, it was reported that only 50 out of 1,000 community residents (comprising a mix of citizens and non-citizens) came forward to undergo free swab tests. ${ }^{20}$

This is not to say that stateless and migrant communities did not take the risks of COVID-19 seriously. Many families that ANAK engaged with were very concerned about themselves and their loved ones falling ill. However, difficulties accessing reliable information, as well as fears of arrest and detention, were factors that contributed to their alienation from health authorities.

16 Wahab (n 5) 4.

17 'Raids Came Only after Illegals Refused to Be Tested, Says Minister', Free Malaysia Today (online, $31 \quad$ May 2020)

<https://www.freemalaysiatoday.com/category/nation/2020/05/31/raids-came-only-afterillegals-refused-to-be-tested-says-minister/ $>$.

18 Muguntan Vanar, 'Covid-19: 1,600 in Pulau Gaya Screened So Far, Three Positive Cases Detected', The Star (online, 31 March 2020) $<$ https://www.thestar.com.my/news/nation/2020/03/31/covid-19-1600-in-pulau-gayascreened-so-far-three-positive-cases-detected $>$.

19 'Medical Charge Exemption for Suspected/Infected Foreign Patients and Contacts for Suspected/Infected Foreign Patients' (Pengecualian Caj Perubatan Kepada Pesakit Warga Asing Yang Disyaki / Dijangkiti Serta Kontak Kepada Pesakit Yang Disyaki Dan Disahkan Dijangkiti)' (Communication, Ministry of Health Malaysia Finance Division, 29 January 2020) <http://www.moh.gov.my/index.php/database_stores/store_view_page/31/375>.

20 Olivia Miwil, 'More Holistic Approach Needed to Address COVID-19 Among Semporna Islanders', New Straits Times (online, 20 October 2020) $<$ https://www.nst.com.my/news/nation/2020/10/633740/more-holistic-approach-neededaddress-covid-19-among-semporna-islanders $>$. 


\section{CONCLUSION AND RECOMMENDATIONS}

The chronic exclusion of stateless and legally marginalised populations, particularly in times of health crises, is dangerous not only to these communities, but to the health and wellbeing of whole societies. ANAK's grassroots work has demonstrated that the denial of citizenship is in itself a major health risk. The authors make the following policy recommendations in the hope that they will be generalisable beyond the Malaysian context.

\section{A Treat Stateless People as Humans, Not Security Risks}

Scapegoating migrants for the spread of COVID-19, and enacting punitive measures against them, will only undermine the public health effort to contain an infectious disease that does not discriminate on the basis of legal status. Stateless and other legally marginalised communities should be considered priority populations in pandemic response measures due to their longstanding vulnerabilities, rather than vectors for disease that need to be contained.

\section{B Listen, Learn and Adapt}

Public health information campaigns geared toward the general population may not be accessible or appropriate for stateless and legally marginalised communities, who face qualitatively different constraints and may have unique needs. It is vital that governments and civil society actors work together to understand the situation on the ground for stateless communities and adapt communication strategies and other public health interventions accordingly. For example, social media tools, which allow for bidirectional engagement and the delivery of tailored messages to targeted demographics, may be a low-cost yet powerful way to reach the hard-to-reach.

\section{Recognise That Health is a Human Right, Regardless of One's Legal}

Status

Access to health services for legally marginalised populations should not only be extended on a conditional or reactionary basis. Providing enduring and unconditional access to healthcare for all, irrespective of legal status, will foster inclusive societies that are more resilient to public health crises. It is therefore crucial that governments 'leave no one behind' when it comes to the basic human right to health - whether it is during this current COVID-19 pandemic or beyond it. 